\title{
Knowledge-based productivity in 'low-tech' industries: evidence from firms in developing countries
}

Citation for published version (APA):

Goedhuys, M., Janz, N., \& Mohnen, P. (2008). Knowledge-based productivity in 'low-tech' industries: evidence from firms in developing countries. UNU-MERIT, Maastricht Economic and Social Research and Training Centre on Innovation and Technology. UNU-MERIT Working Papers No. 007

Document status and date:

Published: 01/01/2008

Document Version:

Publisher's PDF, also known as Version of record

\section{Please check the document version of this publication:}

- A submitted manuscript is the version of the article upon submission and before peer-review. There can be important differences between the submitted version and the official published version of record.

People interested in the research are advised to contact the author for the final version of the publication, or visit the DOI to the publisher's website.

- The final author version and the galley proof are versions of the publication after peer review.

- The final published version features the final layout of the paper including the volume, issue and page numbers.

Link to publication

\footnotetext{
General rights rights.

- You may freely distribute the URL identifying the publication in the public portal. please follow below link for the End User Agreement:

www.umlib.nl/taverne-license

Take down policy

If you believe that this document breaches copyright please contact us at:

repository@maastrichtuniversity.nl

providing details and we will investigate your claim.
}

Copyright and moral rights for the publications made accessible in the public portal are retained by the authors and/or other copyright owners and it is a condition of accessing publications that users recognise and abide by the legal requirements associated with these

- Users may download and print one copy of any publication from the public portal for the purpose of private study or research.

- You may not further distribute the material or use it for any profit-making activity or commercial gain

If the publication is distributed under the terms of Article $25 \mathrm{fa}$ of the Dutch Copyright Act, indicated by the "Taverne" license above, 


\title{
UNITED NATIONS UNIVERSITY
}

\author{
UNU-MERIT
}

\section{Working Paper Series}

\section{\#2008-007}

Knowledge-based productivity in 'low-tech’ industries: evidence from firms in developing countries

\author{
Micheline Goedhuys, Norbert Janz and Pierre Mohnen
}




\title{
Knowledge-based productivity in 'low-tech' industries: evidence from firms in developing countries
}

\author{
Micheline Goedhuys ${ }^{1}$ Norbert Janz ${ }^{1,2}$ and Pierre Mohnen ${ }^{1,3}$
}

${ }^{1}$ UNU-MERIT, Maastricht, the Netherlands;

${ }^{2}$ Aachen University of Applied Sciences, Aachen, Germany;

${ }^{3}$ University of Maastricht, Maastricht, the Netherlands

\begin{abstract}
Using firm level data from five countries - Brazil, Ecuador, South Africa, Tanzania and Bangladesh - this paper examines the knowledge-based determinants of productivity of firms active in food processing, textiles, and garments and leather products. In particular, it seeks to investigate the importance of various sources of knowledge in explaining productivity in the different industries. The knowledge sources driving productivity performance are very different across sectors. In food processing, firm productivity is most strongly affected by quality of management and foreign ownership linkages. In textiles, firms raise productivity levels by importing new machinery and through research and development. In garments and leather products, R\&D and design activities, high quality management and licensing technology from foreign firms are significant productivity determinants. Firms' productivity levels are further depressed by regulatory and financial constraints.
\end{abstract}

Keywords: productivity, knowledge, R\&D, developing countries, food processing, textiles, garments, leather

JEL classification: D24, L66, L67, O14, O31

Corresponding author:

Micheline Goedhuys, UNU-MERIT, Keizer Karelplein 19, 6211 TC Maastricht, The Netherlands, Tel: +31 43 3884480; Fax: +31 43388 4499, Email: goedhuys@merit.unu.edu

\section{UNU-MERIT Working Papers}

ISSN 1871-9872

Maastricht Economic and social Research and training centre on Innovation and Technology, UNU-MERIT

UNU-MERIT Working Papers intend to disseminate preliminary results of research carried out at the Centre to stimulate discussion on the issues raised. 


\section{Introduction}

Ensuring sustained economic growth and creating productive capacities to reduce poverty and foster employment is still the major concern in development economics and development policy. As a majority of developing countries open up their economies, manufacturing firms in these countries are facing the fierce competitive conditions that today govern the global economy. The process of globalization heavily criticized in the industrialized world is seen as both a challenge and an opportunity in the developing economies. Depending on their competitiveness they may catch-up faster or fall behind even further.

Global competitiveness increasingly depends on the ability to assimilate, master and improve technologies in order to produce high-quality products for international markets. While the importance of knowledge is generally recognised for high- or medium-tech industries, it has long been neglected for low-tech industries (von Tunzelmann and Acha, 2005). Yet, for more traditional manufacturing sectors such as food processing, textiles and garments, and even primary production - industries in which developing countries typically have a revealed comparative advantage - using up-to-date technology in production and distribution is crucial as well. Firms have to build and increase managerial and technological capabilities, i.e. to develop competences to increase productivity and profitability and to adjust to market conditions (UNCTAD, 2007).

Firms engage in a variety of activities to reduce costs, improve output quality and develop new products and markets. From the perspective of the firm these activities are innovative activities since they incorporate a strong component of technological learning and may result in products and production processes that are new to the firm. Investment in, and mastery of, new machinery and equipment is still the most important way for technological learning in developing countries (Knell, 2006) leading to the improvement of production processes. Purchasing licenses of production and distribution rights is a way to get access to new technologies incorporating $\mathrm{R} \& \mathrm{D}$ from developed countries. Using new technologies requires skills. Improving human capital by formal education and continuous R\&D activities increases firms’ absorptive capacity, thereby facilitating technology adoption and mastery. It offers possibilities to generate improvements and follow-up innovations. 
Empirically, it remains an open question how important different sources of knowledge acquisition are for firm performance and what explains the heterogeneity of productivity of firms in developing countries. Clearly, the conditions for technological learning may differ across countries, industries and firms. Countrywise, firms are part of a system in which institutions and other organizations play a major role in the process of learning and competence building. As such, the level of development of financial markets, supportive innovation policies, regulatory and administrative burdens but also more subtile habits and practices and trust among local business community may affect the learning process (Mytelka, 2000). Competences are also very much industry-specific (Fai and Tunzelmann, 2000) and the drivers of innovation and technological change are equally so (Pavitt, 1984, Malerba, 2004). Malerba (2006) refers to sectoral systems of innovation to indicate the differences across sectors in the organisation of innovative activities, actors and characteristics involved. It is our purpose to present new evidence using firm level data from different countries to shed light on how important different sources of knowledge acquisition are for the performance of firms in different industries.

We focus our analysis on the three low-tech-sectors that are of major imporance to developing countries in terms of value added or exports: agro-processing (especially food and beverages), textiles as well as garments and leather products. By focussing on these sectors and analysing them separately, we take into account that innovation and learning are industry specific. This allows us to gain insights into the sector specific characteristics and driving forces of productivity.

New firm-level data sets have recently been made available that allow a quantitative analysis of the impact of different technological activities on firm performance. Several developing countries have conducted large-scale surveys at the firm or plant level providing insights into firm behaviour and performance given the conditions they are operating in. We use the Investment Climate Surveys (ICS) of the World Bank which use a relatively harmonised core questionnaire. The surveys contain a wide range of information on sampled individual establishments: inputs, outputs, ownership structure, industry structure, financial conditions, and questions regarding R\&D efforts, training, and innovation. We use the ICS data from five different countries to study a set of sources of technological capability and their impact on productivity. 
In a related study on Tanzania (Goedhuys et al., 2006), we found that the typical technology variables, R\&D and product or process innovation, did not explain any significant variation in productivity between firms, while institutional aspects of the business environment did have an impact on firm performance. Building further on these findings, we are interested in investigating whether it requires a certain level of economic and institutional development in support of competence building, for certain technological and learning efforts to start paying off in terms of productivity. Therefore, in choosing the countries, we decided to include both least developed countries (LDCs) according to the classification of the United Nations ${ }^{1}$ as well as countries that are well embarked on a process of catching up. Least developed countries face more severe problems to be integrated in the world value chain. The share of all LDCs in world exports is still marginal and stagnating in most industries (UNCTAD, 2007)

Apart from the varying level of economic development, several additional criteria were taken into account to select the countries for the analysis, such as the importance of at least one of the sectors for the country's export structure or manufacturing employment, a geographical spread over different continents, and last but not least, the availability of a relatively harmonised core data set covering the period 2000-2002. This resulted in the selection of two Latin American countries, Brazil and Ecuador, two African countries, South Africa and Tanzania, and one Asian country, Bangladesh.

Table 1 presents the importance of the selected industries in these five countries, in terms of value added and employment. It underscores the importance of the food processing industry in all countries, but especially in Ecuador and Tanzania. In addition, it highlights the specialisation of Bangladesh in the production of textiles and labour intensive garments. Among the five countries Brazil has a comparative advantage in the production of leather products and South Africa in other products than the four studied in this paper.

\section{INSERT TABLE 1}

1 By the year 2007, the United Nations classified 50 countries as LDCs based on criteria regarding gross national income (GNI) per capita as well as what they call "human assets" (health, schooling, literacy) and "economic vulnerability" (stability of production and exports, size of population and others). Most of these countries are located in Sub-Saharan Africa, quite a few in Asia (see UNCTAD 2007). 
The structure of the paper is as follows. Section two highlights some of the characteristics of technology and technological change in the industries under study. Section three presents the empirical model. In section four, data sources and the selection and definition of variables are discussed. The results of the analysis are presented in section five. Section six concludes.

\section{Characteristics of innovation and technological change in food, textiles, garments and leather products}

Although an extensive literature review is beyond the scope of this paper, some important characteristics and driving forces of innovation and technological change in the three industries examined in this paper are worth highlighting.

The agro-processing industry covers a wide variety of activities, of which food processing is the most important one. In recent years, the complexity in the production and distribution of agro-processed products has considerably increased. This is mainly caused by rising standards governing international trade in food products. These standards include food safety requirements - as expressed in sanitary and phytosanitary (SPS) measures implemented by the World Trade Organization (WTO) - but also a variety of standards regarding environmental and social aspects. Traditionally food safety regulations have been seen as non-tariff trade barriers impeding international trade (Henson et al., 2000). But for developing countries where production for food exports is quite often separated from production for local consumption, these quality standards can help to position firms in global high-value food markets (Henson and Jaffee, 2006). The role of the wider institutional context to increase innovation and management capacity becomes increasingly important (Hall, 2005). Individual firms need supporting infrastructure for product testing and certification. They require the support of business associations that develop standards in strategic sectors and spread knowledge and information on for instance packaging and transportation. Large firms develop backward linkages to control primary production and quality of inputs.

The importance of interaction between firms supported by institutions and organizations for the creation and transmission of knowledge is stressed in the innovation systems approach 
(Freeman, 1987, and Lundval, 1992). Extended to peculiarities of developing countries (Mytelka, 2000), the role played and the limited success experienced by traditional agricultural research institutes is put into perspective (Hall et al., 2006). In general, public agricultural $R \& D$ expenditure is decreasing in many developing countries. Private $R \& D$, which is still at a comparatively low level, has to fil the gap. But, appropriation of gains from $R \& D$ is difficult because enforcement of intellectual property rights (IPR) is still a challenge for most developing countries (Pray and Umali-Deininger, 1998) and firms are not sufficiently specialized to protect their innovations using IPR (Gehl Sampath, 2007).

For the individual agro-processing firm, the quality of the management is the key factor to source and assimilate information on market requirements and to manage relationships and linkages (Henson and Jaffee, 2006). Gehl Sampath (2007) illustrates these issues for the agroprocessing industry in Bangladesh. Large firms secure the supply of agricultural inputs through contractual arrangements with growers. Small firms are not involved in production and suffer from unreliable supply due to a lack of efficient channels of collaboration between farmers and agro-processors. In addition, their major concern is to ensure food quality. They call for an expanded mandate of their Bangladesh Agro-processors Association, in order to have better provision of testing, grading and packaging services, improved access to information on international markets and improved technologies. Their exports are constrained by SPS measures, as they cannot control the amount of fertilizers and other farmlevel inputs that need to be declared in certification procedures.

The textile industry is often studied together with the garment industry. These industries are vertically related since the textiles industry provides the major material input to garments production. But, they cover firms with differing production technologies and activities that face particular challenges. Audet (2004 and 2007) gives an excellent overview of the driving forces underlying competitiveness in the textiles and garments value chain in the light of adjustments following the end of the Agreement on Textiles and Clothing (ATC) ${ }^{2}$. He

2 From 1974 to 1995 international trade in textiles and garments was governed by the Multi-Fibre Arrangement (MFA) limiting imports of developed economies from developing countries by mostly bilateral quota agreements. The MFA was taken over by the Agreement on Textiles and Clothing (ATC) which gradually returned textiles and garments products to the multilateral rules of the General Agreement on Tarifs and 
describes textile firms as relatively capital-intensive, producing textiles for both clothing and non-clothing applications like car seats. Innovations in textiles machinery have significantly increased the speed of operations and have resulted in significant productivity gains. The use of modern machinery - mainly imported from Western Europe or Japan (Audet, 2004) stands out as crucial (Gruber, 1998, Barba Navaretti et al., 2004, Gehl Sampath, 2007). In Asian LDCs this imported machinery is often relocated after use in other Asian countries (Rasiah, 2007). Innovation in the chemical industry is equally important for the development of new textiles in non-natural fibre and for the improvement of its quality. The ability of firms to adopt these new products and processes is crucial for their productivity. R\&D is regarded to play a minor role with the exception of industrial textiles where material technology is a crucial factor (Nordas, 2004).

On the contrary, the garments industry (sometimes referred to as clothing or apparel industry) is low-skilled labour intensive, especially in the garments assembly stage. This involves delicate handling and sewing of garment components. Here, the basic production technology has not changed much in the recent past (Nordas, 2004). The pre-assembly stage, however, involves design and marking of patterns as well as cutting of textile components requiring advanced design skills and the ability to use CAD/CAM methods (Audet, 2004).

International specialisation and division of labour in the MFA and ATC periods resulted in low wage countries such as Bangladesh or Kenya ${ }^{3}$ being involved in the assembly stage, with pre-assembly stages and retailing activities located in developed countries (McCormick, 2001). Large retailers and brand marketers from developed countries got actively involved in garments manufacturing by sourcing from several low wage countries through licensing arrangements and subcontracting. In doing so, they exerted substantial influence on the technical skills of local garment producers, by imposing quality standards and working conditions (Gehl Sampath, 2007) and instructing them on fashion-related preferences and

Trade (GATT) and the World Trade Organization (WTO), respectively. In fact, some of the most restrictive quotas were just removed by end of the year 2005 (Nordas 2004, Yang and Mlachila, 2007).

3 Both, the United States as well as the European Union offered non-reciprocal preference programs for textiles and clothing products from least developed countries, e.g. the African Growth and Opportunity Act (AGOA) in the United States and the Everything But Arms Initiative (EBA) of the European Union (Hayashi, 2007). 
market trends. The acquisition of design skills and market-related knowledge and the ability to establish forward linkages into distribution channels have become even more important in the post ATC period, in which China emerged as an increasingly fierce competitor (Rasiah, 2007). In Bangladesh, firms continue to lack design capabilities and buy designs from Indian designers or follow buyer specifications (Gehl Sampath, 2007).

Many studies focus on industrial districts and local clusters in garments illustrating success and failure of cluster firms to develop these design and marketing capacities (e.g. for Colombia: Pietrobelli and Barrera, 2002; for Mexico: Bair and Gereffi, 2001; for Kenya and South Africa: McCormick, 1999; for Peru: Visser, 1999; for Brazil: Schmitz, 1999). In general, the impact of the clusters on firms innovative capacity seems to be limited.

Several authors stress other non-price and institutional factors such as the time factor (Tewari, 2006). Turnaround times in fashion sensitive consumer markets are very short and the ability to deliver a variety of goods in time is equally crucial. This, however, does not depend only on the individual firm, but especially on transit time for shipments, the efficiency of port infrastructure and customs services (Audet, 2004, Gehl Sampath, 2007, Rasiah, 2007). Countries with quality textile producers able to supply domestic garments producers - more integrated suppliers such as China - are therefore likely to have a time advantage over countries that have to source textiles from abroad.

Leather products is an interesting industry for many developing countries that are endowed with abundant livestock and the share of developing countries in leather products production and trade has increased, at the expense of the activities in developed economies (Muchie, 2000). Technological requirements facing the leather industry in developing countries are very similar to those in the garments industry, given that they produce goods for an equally fashion-oriented end consumer market. Sourcing companies and agents similarly exert strong influence in the entire supply chain, including design, product specificiations, the production process and the implementation of quality systems (UNIDO, 2004). In addition, apart from the product specifications and sensitivity to brand names, consumers raise their concerns regarding environmental and social aspects of the production process, especially in tannery. Tannery businesses, to qualify for ISO 14000 certification, need to take into consideration a wide perspective of environmental issues. Establishing linkages, forming market alliances, 
developing design skills and marketing (branding) capacities are mechanisms businesses use to upgrade themselves in the value chain.

It is against this competitive setting and institutional background that individual firms take decisions regarding design, skills development, technology licensing, establishment of linkages etc, in order to improve their competitive position. In what follows, we will investigate the effect and relative importance of these activities on productivity.

\section{Empirical model}

To analyze the effects of the various technological activities on firm level productivity we estimate a production function in which firms' value added $Y_{i}$ is a function of the traditional factors of production, physical capital $K_{i}$ and labour $L_{i}$, and of total factor productivity $\mathrm{A}(\cdot)$, that is itself determined by a set of variables $\mathrm{Z}_{\mathrm{i}}$, capturing capability building activities, and a set of variables $\mathrm{I}_{\mathrm{i}}$, representing the influence of institutional variables. We assume a nonconstant returns to scale Cobb-Douglas functional form as a first-order approximation to a general production function:

$Y_{i}=A\left(Z_{i}, I_{i}\right) K_{i}^{\alpha} L_{i}^{\beta} e^{\varepsilon_{i}}$

Elasticities of output with respect to physical capital and labour are denoted as $\alpha$ and $\beta$, respectively. Constant returns to scale occur if $\alpha+\beta=1$, which will be tested empirically. The stochastic term $\varepsilon_{i}$ summarizes unobserved factors affecting firms’ output.

Rewriting this equation in terms of labour productivity and taking the logarithmic form, equation (1) becomes:

$\ln \left(Y_{i} / L_{i}\right)=\ln A\left(Z_{i}, I_{i}\right)+\alpha \ln \left(K_{i} / L_{i}\right)+(\alpha+\beta-1) \ln L_{i}+\varepsilon_{i}$

where the coefficient of $\ln L_{i}$ measures the deviation from constant returns to scale. 
We further control for differences in capacity utilization between firms. Indeed, when firms operate at higher capacity, they are able to produce more with the same amount of inputs. Part of total factor productivity (TFP) can therefore be ascribed to capacity utilization. We therefore introduce a variable $u_{i}$ measuring capacity utilization, the coefficient of which $\gamma$ is expected to be positive.

This estimation is done on a pooled data set including firms from the five countries. However, since the drivers of technological change appear industry-specific, as described in the previous section, the augmented production function is estimated separately for the different industries. We thus estimate one equation for food processing firms, one equation for textile firms and a third equation for garments and leather products taken together. Both garments and leather products serve equally fashion-sensitive markets with labour intensive production processes, hence the sources of productivity are assumed to bear strong similarities.

As a consequence of this approach, country dummy variables $D_{i j}$ are introduced to pick up the country-specific effects related to government policies and unobserved institutional factors. The estimating equation therefore becomes

$$
\ln \left(Y_{i} / L_{i}\right)=\sum_{j=1}^{n-1} \delta_{j} D_{i j}+\ln A\left(Z_{i}, I_{i}\right)+\alpha \ln \left(K_{i} / L_{i}\right)+(\alpha+\beta-1) \ln L_{i}+\gamma u_{i}+\varepsilon_{i}
$$

where $D_{\mathrm{ij}}$ are country dummy variables and $\mathrm{I}$ is a vector of institutional control variables.

We also want to test whether the technology variables have the same impact at different levels of development. We therefore interact the technological variables with a binary variable for firms active in LDC countries (in this case Bangladesh and Tanzania) in the following way:

$$
\ln \left(Y_{i} / L_{i}\right)=\sum_{j=1}^{n-1} \delta_{j} D_{i j}+\ln A\left(Z_{i}, Z_{i} * L D C_{i}, I_{i}, I_{i} * L D C_{i}\right)+\alpha \ln \left(K_{i} / L_{i}\right)+(\alpha+\beta-1) \ln L_{i}+\gamma u_{i}+\varepsilon_{i}
$$

This equation is estimated using OLS, estimating the mean effects of explanatory variables on the logarithm of value added per employee. In addition, to control for the effect of outliers the estimation is also done using least absolute deviations (LAD). Additionally, a weighted OLS is also performed, to control for the unequal size of the samples in the different countries. 
Several remarks need to be made to interpret the coefficients. To the extent that technological variables are correlated with productivity, a simultaneity bias may exist in the estimated coefficients. Ideally the use of panel data would help avoiding this problem of simultaneity bias. The data available are cross-section data (see next section), hence we have no straightforward solutions to this problem. Multicollinearity problems may arise as more technology variables are added to the equation. It is likely for instance that firms that invest in imported machinery engage systematically in the training of workers to use these new machines. A selection of variables is therefore needed, which is discussed below in section 4.2 .

\section{Data sources and definition of variables}

\subsection{Data}

The data used in the analysis are retrieved from the World Bank Investment Climate Surveys (ICS, see World Bank, 2004). The ICS is an important effort coordinated by the World Bank to collect harmonised micro data in developing and least developed countries. By intensive face-to-face interviews, firms are surveyed on conduct and performance as well as their perception on several aspects related to the business environment. The resulting ICS is a rich data set gathering plant-level information helping to understand how technological conditions and institutional constraints affect the operations and performance of firms. The survey questionnaire contains a series of questions on firms' behaviour, their position on financial, factor and output markets accompanied by information on infrastructure, regulation, international trade, innovation and learning as perceived by the firm. To benchmark firms' performance, variables such as sales are included which allow calculating value added and productivity, respectively.

The uniqueness of the ICS lies in the fact that all countries use questionnaires with a set of harmonised core questions that facilitate cross country comparisons. This provides an advantage over typical innovation surveys that have been started to being conducted in several 
developing countries, following the example of the Community Innovation Surveys (CIS) coordinated by EUROSTAT. While these innovation surveys are focused on technological aspects and innovative activities, including sources of information, collaboration, obstacles to innovation etc., in developing countries they have been tailored to the country-specific needs to such an extent that cross-country comparisons have become difficult and sometimes hardly possible.

For the analysis we used the individual country ICS data sets for Brazil, Ecuador, South Africa, Tanzania and Bangladesh. In these countries, firms were selected on the basis of a stratified random sample. The strata were defined by industry classification, size classes and regional location. Due to the different levels of economic development and size of the economies, the number of firms in the samples varies considerably across countries. Table 2 gives an overview of the number of firms in the sample used for our empirical analysis ${ }^{4}$, by country and industry, and includes the number of exporting and foreign owned firms. The largest number of firms is found in the Brazilian sample, the smallest number in the Tanzanian sample. In line with their economic activity, Brazil and Bangladesh have a relatively larger number of firms in the garments and leather industry. In Ecuador, South Africa and Tanzania, it is the food and beverages industry that contains the largest number of firms. The percentage of foreign owned firms rarely exceeds $10 \%$, but the percentage of exporters among the sampled firms is close to $40 \%$ on average.

INSERT TABLE 2

\subsection{Variable definitions}

In line with the model developed in section three, the dependent variable is LABOUR PRODUCTIVITY, measured by the value added per employee, in natural logarithmic terms.

4 Due to item non-response on variables crucial for the analysis, a number of observations had to be excluded from the data set, reducing the number of firms to the numbers shown in table 2. 
Value added was calculated as the value of total sales minus material purchases and costs of fuel and electricity. All values are for the final year covered by the survey, mostly $2002^{5}$.

The traditional explanatory variables for labour productivity are the capital intensity, CAPITAL/LABOUR ratio (in logs), and the degree of returns to scale measured by the coefficient of LABOUR (in logs). Capital is measured as the firm's end-of-period capital stock. Labour input is measured by total number of employees in 2002, which is the sum of the number of permanent workers and the average number of temporary workers employed in 2002.

Firms can choose different paths to increase technological capabilities in the production of goods. One way is to adopt technology from foreign sources. Firms can source technology from abroad through established ownership linkages that facilitate transfer of knowledge or organizational capabilities. A dummy variable FOREIGN indicating whether the firm has a positive share of foreign ownership captures this effect. Alternatively firms can directly make use of external technology through licensing agreements with other firms. The dummy variable LICENSE marks whether technology has been licensed from a foreign company. Firms can also introduce new technologies by importing new vintage machinery for more efficient production. The dummy variable IMPMAC is therefore included indicating a firm having imported new machinery in the period 2000-2002. It should be noted that the only information we had for Ecuador was the firms' total investment, not specifically the imported part of it. Because of this difference in measurement for Ecuador, the dummy IMPMAC was split into two dummies: ECUIMPMAC, equalling one if the Ecuadorian firm invested, and NECUIMPMAC equal to one if firms in Brazil, Tanzania, Bangladesh or South Africa invested in imported machinery and equipment.

Firms conduct R\&D for two reasons: as an alternative to imported technology and as a way to build up absorptive capacity to benefit from outside R\&D (Cohen and Levinthal, 1989). RD is a binary variable indicating a firm that was engaged in in-house $R \& D$ or design activities.

\footnotetext{
5 Values are for fiscal year 2002 in Brazil and Tanzania, for calendar year 2002 in Ecuador and South Africa,
} and for fiscal year 2002 or calendar year 2001 in Bangladesh. 
Notice that $R \& D$ here includes design as opposed to the narrower definition of $R \& D$ from the Frascati manual (OECD, 2002) because design is regarded as a core activity in the garments industry. To efficiently convert research results into marketable products and to absorb external market information the quality of management is crucial. EDUCGM is a dummy variable for managers with higher education. $R \& D$, education of the management, licensing, foreign ownership and investment in embodied knowledge are the key variables capturing technological efforts and were selected for the empirical analysis.

Other interesting information is available, such as on the amount of training and education, and the proportion of skilled labor in total personnel. Inclusion of too many of the innovation variables, however, results in collinearity problems inflating standard errors and thereby reducing the statistical significance of the explanatory variables. As many of the innovation activities are indeed undertaken simultaneously, many of the corresponding variables are highly correlated with each other. The training variable and the proportion of skilled labor were insignificant in various experiments and were therefore dropped from our specification.

Interestingly, there is also information on innovation output, which could provide an alternative approach to measuring the impact of innovation on performance. One question relates to product innovation and asks if the firm has introduced a new product over the last three year period. Another question asks if the firm has introduced new technology that substantially changed the way the main product is produced. The questions are uniform for all countries except Bangladesh, where product innovation refers to a two or five year period depending on the industry, and the question on process innovation is not asked. Both variables reveal relatively high mean values, with the proportion of product innovators reaching 62\% in Brazil, 76\% in South Africa, 50\% in Ecuador, 26\% in Tanzania and 52\% in Bangladesh. The proportion of process innovators is 68\% in Brazil, 67\% in South Africa, $37 \%$ in Ecuador and 32\% in Tanzania.

We did several estimations including the innovation output variables as explanatory variables in the regression, either alone or in combination with the innovation input variables, and with the smaller sample excluding Bangladesh for process innovation. In none of the estimations the results revealed that product or process innovation in previous years could explain higher levels of productivity in 2002. This finding is remarkable, yet not surprising. The impact of innovations should also be related to the initial productivity position of the firms or to 
individual effects. For instance, process innovation even had a negative and significant coefficient, and this may indicate that less productive firms have been under severe pressure to streamline the production to remain in business. In our cross-section results explaining the level of productivity in 2002, the positive effect may not show up. We therefore chose to focus more on those technological variables that serve as inputs to the innovation process and are more strongly related to productivity levels than to productivity growth.

Finally, two variables were introduced to control for the institutional environment firms are operating in. In many least developed countries, financial markets are characterized by important failures to obtain credit to finance business operations. The dummy variable CREDIT captures the benefit of having an overdraft facility with a bank or financial institution that allows flexible access to short-term credit. Firms were also asked to indicate the proportion of senior management's time that is spent in dealing with requirements imposed by government regulations such as completing forms, dealing with officials etc. REGULTIME thus takes a value between zero and one. ${ }^{6}$

Table 3 presents some summary statistics, by industry and country, for the variables used in the regression. Monetary values are transformed into US-dollars taking exchange rates for the end of December 2002. ${ }^{7}$ On average, both economic variables and variables capturing technological capabilities vary considerably between industries and countries, reflecting differences in technology and in the state of development.

\section{INSERT TABLE 3}

6 Being member of a business association, which we found to be important for Tanzanian firms in Goedhuys et al. (2006) was insignificant when added to the explanatory variables and therefore not included in the crosscountry industry specific regressions.

7 Exchange rates for Brazil and South Africa are taken from the World Bank Online Exchange Rate Statistics (see http://www.imf.org/external/data.htm), for Tanzania from the Bank of Tanzania website (see http://www.bot-tz.org/Archive/Default.asp\#CurrencyExchangeRates) and for Bangladesh from the appendixs to the Bangladesh Bank annual report 2005-2006 (see http://www.bangladeshbank.org/pub/annual/anreport/ar0506/app21.pdf) . Because of the dollarization of the economy Ecuadorian figures are already expressed in US-dollars. 
Value added per employee as well as capital stock per employee is the lowest in the labour intensive garments and leather industries. In the least developed countries, Tanzania and Bangladesh, value added per employee is lower than in the other countries. This does not hold for capital intensity, which is relatively high in Tanzania where capacity utilization is relatively low. Average firm size in terms of employment is the highest in South Africa and in the garments and leather industry in Tanzania.

Heterogeneity across firms is even more reflected in the variables reflecting firm and country strategies of technology sourcing and competence building. The least developed countries show a considerably lower level of R\&D activities with the exception of garments and leather industries in Bangladesh. As mentioned above, R\&D as measured in the ICS includes design, which is especially crucial for the Bangladesh and Ecuadorian export markets in clothing. In South Africa, R\&D activities are more pervasive than in the other countries. Education of the general management is on average the highest in South Africa and Ecuador and in the garments and leather industries in Bangladesh. The high level of education of management in the Bangladesh garments and leather industries underscores again the importance of this export-oriented industry for Bangladesh. The strategies of acquiring new technology from sources external to the country, i.e. either licensing or buying imported machinery incorporating new technology, are often complementary. ${ }^{8}$ With respect to licensing Brazil and Bangladesh are lagging behind the other countries.

Perceptions regarding the institutional environment are also heterogeneous across countries. As expected, financial markets are less developed in the least developed countries, especially in Tanzania, where the majority of firms do not have access to flexible forms of short term credit. $^{9}$ Time spent in dealing with regulatory and administrative requirements is highest in Tanzania and lowest in Bangladesh and South Africa.

8 For imported machinery, the values for Ecuador are not directly comparable to those of other countries due to differences in measurement. The differences are accounted for in the estimation procedure.

$9 \quad$ The relatively low share of firms having access to credit in the South African textile industry should be taken carefully considering the small number firms in this strata. The same holds for the regulation aspect in the Tanzanian garments and leather industry. 


\section{Differences in knowledge-based total factor productivities across sectors}

Because of apparent heterogeneity across industries, we estimate the Cobb-Douglas specification separately for each industry, but pool the data for the five countries. Table 4 presents the results obtained with specification (3), where differences in total factor productivity (TFP) are explained by various sources of technological knowledge, controlling for access to credit and for regulatory burden. In the second column for each country we also allow some of these effects to be different for the two LDC countries as explained in specification (4). The reference group is formed by Brazilian firms.

We find elasticities of output with respect to capital stock of roughly 29 percent in food processing and the production of garments and leather. It the textiles industry it is slightly lower, around 24 percent. The results do not differ considerably between the two specifications. The hypothesis of constant returns to scale cannot be rejected for all three sectors in both specifications. Productivity increases with capacity utilization, but a statistically significant effect is obtained only for food processing and garments and leather production.

The country dummies indicate significant country differences of TFP in all three sectors. The LDC countries Tanzania and Bangladesh have the lowest level of country-specific TFP effects in all three industries. South Africa scores best in food processing. It remains an open question whether these country specificities are due to differing levels of technological activity, or to other country-specific influences that we cannot observe directly from the data. Especially country specific measurement errors in some variables, like differences in the evaluation of the capital stock or imperfect exchange rates, could show up in the country dummies.

Conducting in-house R\&D activities appears to be important for TFP in the textile and garment industries. In textiles, the coefficient is highest and statistically significant at the $1 \%$ level, indicating that R\&D performing firms have, all other things equal, a 0.4 percent higher TFP level. In garments and leather products the $R \& D$ variable most probably reflects design 
activities, and doing so raises is associated with a 0.12 percent higher level of TFP. In food production, even though a sizeable proportion of firms declare to conduct $R \& D$, doing so is not related to any statistically significant difference in productivity. Although these findings seem counter-intuitive, given that the knowledge intensity is as high in food production as in textiles and garments, it is supported by the literature. Private R\&D in the food industry has long played a minor role in developing countries where R\&D was mostly located in public research institutions. The overall level of private $R \& D$ expenditure is still relatively low and appropriation of R\&D returns is difficult to enforce (see Pray und Umali-Deiniger, 1998). Thus, the effect on productivity is low.

The ability to interact with other agents and support institutions is of greater importance in food and related industries (Hall, 2005 and 2007). This ability is approximated by the quality of management measured by the level of formal education. In the food processing industry, it is indeed significant at the $1 \%$ level and associated with a 50 percent higher level of TFP. In garments and leather products it is related to a 25 percent higher level of TFP. The importance of managerial quality thus seems especially high in industries in which firms need to establish solid forward linkages and capture a variety of market signals with increasing competitive pressures on their product market.

Licensing arrangements with foreign firms is only important for garments and leather product producers. Licensing arrangements allow licensee firms to acquire fashion-oriented product designs externally and facilitated market access when licensors source their products directly from them. For textiles and food processing, licensing arrangements do not produce any significant effect on productivity.

In textiles, it is the import of new machinery and equipment that shows up as a major productivity determinant. This observation is fully in line with other studies mentioning that productivity gains in textiles have resulted from process innovations that improve the speed of operations in textile firms through the introduction of superior spinning and weaving machinery (see Audet, 2004, and Barba Navaretti et al., 2004). Unfortunately, for the Ecuadorian firms, this identical information is missing. The proxy variable total investment does not show up significantly in Ecuador. 
Foreign owned firms appear to have significantly higher levels of TFP only in food processing. Foreign controlled firms have on average 62 percent higher TFP levels. No difference due to foreign ownership shows up in the other industries.

The institutional aspect of regulatory burden has the expected statistically significant impact in textiles and garments: the more senior management's time is wasted on regulatory matters the more depressed is TFP. The coefficients indicate that a one percentage point increase in the proportion of time spent dealing with regulatory requirements depresses productivity by 1 percent. This means that the 10 percent difference between South Africa and Bangladesh, where the average time spent on regulatory matters is 14 and 4 percent respectively, depresses TFP by 10 percent, an effect that is comparable with that of doing or not doing R\&D and design activities in that particular industry. Access to flexible forms of credit also allows firms to be more productive. The effect is high and statistically significant in food processing and garments and leather products, raising TFP by 23 and 20 percent respectively.

In addition, we investigated whether there are differences between LDCs and the more advanced developing countries. This was done interacting the explanatory variables with a dummy variable. For some technology variables, no differential impact on productivity was observed for LDCs when compared with other developing countries, i.e. for licensing, foreign ownership and imported machinery. These interaction terms were therefore dropped for the final estimation. The results in table 4 indicate a weaker link between R\&D and TFP in LDCs, especially in the production of garments and leather, where the interaction coefficient is negative and significant at the $5 \%$ level. Its negative value outweighs the positive coefficient of R\&D and design, implying that the net relationship between R\&D and TFP is negligible in LDCs. The interaction of the financial dummy with the LDC dummy indicates that in the capital-intensive textiles industry access to finance is especially crucial for least developed countries, where financial markets are less developed.

A few checks were conducted to test the robustness of the empirical results. We investigated whether our results were affected by unequal sample sizes. The number of firms from Bangladesh and Brazil for instance were much larger than those from South Africa and Tanzania. We therefore applied a weighted least squares regression, in which firms from every country were given equal weights, i.e. firms from countries with many observations were down-weighted while firms from countries with small samples were given higher 
weight. This estimation did produce only slightly different results from OLS (see table A1 in the appendix). A small effect of $R \& D$ on productivity can be testified even for the food industry, but only at $1 \%$ level of significance, whereas the impact of regulatory burden is no longer significant.

To check for the effect of heterogeneity and especially of potential outliers we estimated the median impact using the Least Absolute Deviation (LAD) estimator. LAD estimators give results for the median in contrast to the mean firm. Once again, the estimation results were very much in line with the OLS results (see table A2 in the appendix). Due to higher standard errors produced by the estimation procedure some results are less pronounced and some coefficients become insignificant. But, overall the previous results are unaffected.

\section{Conclusion}

This paper has used firm data from the Investment Climate Surveys of the World Bank to assess the importance for TFP of various sources technological knowledge in three low-tech industries (food and beverages, textiles, and garments and leather products) and five countries (Brazil, Ecuador, South Africa, Tanzania and Bangladesh). The findings indicate that the the sources of knowledge that raise productivity are highly industry-specific. In the food processing industry firms with higher educated management and foreign ownership are more productive. In the more capital intensive textiles industry, firms raise productivity by conducting their own R\&D and importing new machinery and equipment. In the manufacture of garments and leather products it is the higher education of managers, own R\&D and licensing from abroad that predominates. Institutional variables can also affect productivity. In the leather and garments industry, easy access to bank credit boosts productivity whereas time spent on meeting regulatory matters retards TFP. When comparing the effects of technology sources on LDC and developing countries, we find a significant difference only in leather and garments, where R\&D and design display practically no rate of return in the LDC countries compared to a solid $12 \%$ in developing countries. The results obtained are robust to alternative estimation methods. 
A word of caution is in order, which at the same time points to an interesting direction for future research. The evidence presented in this paper is based on cross-sectional data. It is of course difficult to establish links of causality from cross-sectional data, especially if some of the explanatory variables such as $R \& D$, licensing and importing equipment are under the firm's control. They could increase TFP but equally well be driven by higher TFP. To disentangle these two effects, panel data would be needed. We hope to be able to access such data for firms in developing countries in the near future. 


\section{References}

Almeida, R., Fernandez, A.M., 2006, Openness and Technological Innovations in Developing Countries: Evidence from Firm-Level Surveys, World Bank Policy Research Working Paper 3985, Washington.

Audet, D., 2004, Structural Adjustment in Textiles and Clothing in the Post-ATC Trading Environment, OECD Trade Policy Working Papers, n²4, OECD Publishing.

Audet, D., 2007, Smooth as Silk?: A First Look at the post MFA Textiles and Clothing Landscape, Journal of International Economic Law, 10, 267-284.

Bair, J., Gereffi, G., 2001, Local Clusters in Global Chains: The Causes and Consequences of Export Dynamism in Torreon's Blue Jeans Industry, World Development, 29, 18851903.

Barba Navaretti, G.B., Galeotti, M., Mattozzi, A, 2004, Moving Skills from Hands to Heads: Does Importing Technology Affect Export Performance in Textiles?, Research Policy, 33, 879-895.

Cohen, W.M., Levinthal, D.A., 1989, Innovation and Learning: The Two Faces of R\&D, The Economic Journal, 99, 569-596.

Fagerberg, J., Nelson, R., Mowery, D. (eds.), 2005, The Oxford Handbook of Innovation, Oxford University Press.

Fai, F., von Tunzelmann, N., 2000, Industry-Specific Competencies and Converging Technological Systems: Evidence from Patents, University of Bath School of Management Working Paper 2000.08, Bath.

Fernandes, A., 2006, Firm Productivity in Bangladesh Manufacturing Industries, World Bank Policy Research Working Paper 3988, Washington.

Freeman, C., 1987, Technology and Economic Performance: Lessons from Japan, London.

Gehl Sampath, P., 2007, Intellectual Property and Innovation in Least Developed Countries: Pharmaceuticals, Agro-processing and Textiles and RMG in Bangladesh, A Study for UNCTAD-ALDC Division, Paris.

Goedhuys, M., Janz, N., Mohnen, P., 2006, What drives productivity in Tanzanian manufacturing firms: technology or institutions?, UNU-MERIT working paper 2006039, Maastricht.

Gruber, H., 1998, The diffusion of innovations in protected industries: The textile industry, Applied Economics, 30, 77-83.

Hall, A., 2005, Capacity Development for Agricultural Biotechnology in Developing Countries: An Innovation Systems View of what it is and how to Develop it., Journal of International Development, 17, 611-630.

Hall, A., 2007, Challenges to Strengthening Agricultural Innovation Systems: Where Do We Go from here?, UNU-MERIT Working Paper 2007-38, Maastricht.

Hall, A., Mytelka, L., Oyelaran-Oyeyinka, B., 2006, Concepts and guidelines for diagnostic assessments of agricultural innovation capacity, UNU/MERIT working paper series 2006-017, Maastricht. 
Hayashi, M., 2007, Trade in Textiles and Clothing, Assuring Development Gains in a Rapidly Changing Environment, UNCTAD Series on Assuring Development Gains from the Interational Trading System and Trade Negotiations, New York.

Henson, S., Brouder, A.M., Mitullah, W. (2000), Food Safety Requirements and Food Exports from Developing Countries: The Case of Fish Exports from Kenya to the European Union, American Journal of Agricultural Economics, 82, 1159-1169.

Henson, S., Jaffee, S., 2006, Food Safety Standards and Trade: Enhancing Competitiveness and Avoiding Exclusion of Developing Countries, European Journal of Development Research, 18, 593-621

Hoekman, B. M., Maskus, K.E., Saggi, K., 2005, Transfer to Technology to Developing Countries: Unilateral and Multilateral Policy Options, World Development, 33, 15871602.

Lundvall, B.A. (ed.), 1992, National Systems of Innovation and Interactive Learning, London.

Malerba, F., 2005, Sectoral Systems: How and Why Innovation Differs Across Sectors, in: Fagerberg, J., Nelson, R., Mowery, D. (eds.), 2005, The Oxford Handbook of Innovation, Oxford, 380-406..

McCormick, D., 1999, African Enterprise Clusters and Industrialization: Theory and Reality, World Development, 27, 1531-1551.

Muchie, M, 2000, Leather Processing in Ethiopia and Kenya: Lessons from India, Technology in Society, 22, 537-555.

Mytelka, L.K., 2000, Local Systems of Innovation in a Globalized World Economy, Industry and Innovation, 7, 15-32.

Nordas, H.K., 2004, The Global Textile and Clothing Industry post the Agreement on Textiles and Clothing, WTO Discussion Paper No. 5, World Trade Organization, Geneva.

OECD, 2002, The Measurement of Scientific and Technological Activities, Proposed Standard Practice for Surveys on Research and Development: Frascati Manual, Paris.

OECD, 2004, A New World Map in Textiles and Clothing, Adjusting to Change, Paris, 2004.

Oyelaran-Oyeyinka, B., 2006

Pavitt, K., 1984, Sectoral Patterns of Innovation, Towards a Taxonomy and a Theory, Research Policy, 13, 343-373.

Pietrobelli, C., Barrera, T.O., 2002, Enterprise Clusters and Industrial Districts in Colombia's Fashion Sector, European Planning Studies, 10, 541-562.

Pray, C.E., Umali-Deininger, D., 1998, The Private Sector in Agricultural Research Systems: Will it Fill the Gap?, World Development, 26, 1127-1148.

Rasiah, R., 2007, Garment Exports from Asian LDEs: Can it Be Sustained?, UNCTAD Least Developed Countries Report 2007, Background Paper 8, Geneva.

Schmitz, H., 1999, Global Competition and Local Cooperation: Success and Failure in the Sinos Valley, Brazil, World Development, 27, 1627-1650.

Söderbom, M., Teal, F., 2006, The Determinants of Survival among African Manufacturing Firms, Economic Development and Cultural Change 54, 533-555. 
Tewari, M., 2006, Is Price and Cost Competitiveness enough for Apparel Firms to Gain Market Share in the World after Quotas? A review, Global Economy Journal, 6, Issue 4, Article 5.

UNCTAD, 2007, The Least Developed Countries Report, 2007, New York.

UNIDO, 2004, A blueprint for the African leather industry, a development, investment and trade guide for the leather industry in Africa, Vienna.

Visser, E.-J., 1999, A Comparison of Clustered and Dispersed Firms in the Small-Scale Clothing Industry of Lima, World Development, 27, 1553-1570.

von Tunzelmann, N., Acha, V. (2005), Innovation in 'Low-Tech’ Industries, Fagerberg, J., Nelson, R., Mowery, D. (eds.), 2005, The Oxford Handbook of Innovation, Oxford, 407-432.

World Bank, 2004, World Development Report 2005: A Better Investment Climate for Everyone, Washington.

Yang, Y., Mlachila, M., 2007, The End of Textiles Quotas: A Case Study of the Impact on Bangladesh, Journal of Development Studies, 43, 675-699. 
Table 1.: Country statistics and the importance of selected industries

\begin{tabular}{|c|c|c|c|c|c|}
\hline & \multicolumn{3}{|c|}{ Developing countries } & \multicolumn{2}{|c|}{ LDC countries } \\
\hline & Brazil & Ecuador & $\begin{array}{l}\text { South } \\
\text { Africa }\end{array}$ & Tanzania & Bangladesh \\
\hline $\begin{array}{l}\text { GDP/Capita } \\
\text { (in constant } 1995 \text { US\$) }^{\text {a. }}\end{array}$ & 4642 & 1796 & 4020 & 207 & 396 \\
\hline $\begin{array}{l}\text { Population } \\
\text { (in millions) }^{\text {a. }}\end{array}$ & 174 & 13 & 45 & 35 & 135 \\
\hline $\begin{array}{l}\text { Manufacturing Value } \\
\text { Added (\% of GDP) }\end{array}$ & 13 & 11 & 19 & 8 & 16 \\
\hline Food and Beverages & & & & & \\
\hline$\%$ of MVA in GDP ${ }^{b}$ & 16.9 & 31.9 & 16.7 & 32.5 & 9.8 \\
\hline$\%$ of employment in man ${ }^{\mathrm{b} .}$ & 20.9 & 45.0 & 15.2 & 34.4 & 6.8 \\
\hline RCA in fresh food ${ }^{c .}$ & 3.88 & 8.96 & 2.25 & 19.56 & 1.44 \\
\hline RCA in processed food ${ }^{c .}$ & 3.11 & 2.65 & 0.97 & 0.74 & n.a. \\
\hline Textiles & & & & & \\
\hline$\%$ of MVA in GDP ${ }^{b}$ & 2.3 & 2.0 & 1.7 & n.a. & 13.1 \\
\hline$\%$ of employment in man ${ }^{\mathrm{b} .}$ & 5.0 & 6.0 & 4.9 & $25.8 *$ & 29.9 \\
\hline $\mathrm{RCA}^{\mathrm{c} .}$ & 0.55 & 0.29 & 0.28 & 0.30 & 2.56 \\
\hline Garments & & & & & \\
\hline$\%$ of MVA in GDP ${ }^{b .}$ & 1.4 & 0.9 & 2.1 & n.a. & 19.3 \\
\hline$\%$ of employment in man ${ }^{\mathrm{b} .}$ & 7.8 & 4.8 & 7.1 & $1.5 *$ & 47.0 \\
\hline $\mathrm{RCA}^{\mathrm{c} .}$ & n.a. & 0.12 & 0.66 & 0.21 & 22.95 \\
\hline Leather products & & & & & \\
\hline$\%$ of MVA in GDP ${ }^{b .}$ & 2.1 & 0.4 & 0.7 & n.a. & 8.0 \\
\hline$\%$ of employment in man ${ }^{\mathrm{b} .}$ & 7.3 & 2.0 & 1.6 & 2.9 & 2.3 \\
\hline $\mathrm{RCA}^{\mathrm{c} .}$ & 3.09 & n.a. & 0.41 & 0.39 & 2.95 \\
\hline
\end{tabular}

Sources: a. World Development Indicators, 2004 (values are for 2002); b. UNIDO Industrial Statistics, data are for 2004 for Brazil, Ecuador, South Africa, 1999 for Tanzania (1995 when indicated by *), 1998 for Bangladesh; c. International Trade Centre, based on COMTRADE data, 2002.

Note: n.a. means not available from the mentioned source; MVA = manufacturing value added; man = manufacturing; RCA (revealed comparative advantage) values are only calculated for important export product categories. 
Table 2: Composition of the sample: total number of firms, number of exporting firms and number of foreign owned firms, by industry and country

\begin{tabular}{|l|c|c|c|c|c|c|c|c|c|}
\hline & \multicolumn{3}{|c|}{ Food and beverages } & \multicolumn{3}{c|}{ Textiles } & \multicolumn{3}{c|}{$\begin{array}{c}\text { Garments and } \\
\text { leather products }\end{array}$} \\
\hline & Total & Exporting & $\begin{array}{c}\text { Foreign } \\
\text { owned }\end{array}$ & Total & Exporting & $\begin{array}{c}\text { Foreign } \\
\text { owned }\end{array}$ & Total & Exporting & $\begin{array}{c}\text { Foreign } \\
\text { owned }\end{array}$ \\
\hline Brazil & 111 & 48 & 3 & 93 & 36 & 8 & 529 & 113 & 0 \\
\hline Ecuador & 49 & 12 & 4 & 20 & 10 & 2 & 23 & 5 & 1 \\
\hline South Africa & 36 & 15 & 4 & 12 & 9 & 3 & 25 & 17 & 3 \\
\hline Tanzania & 61 & 24 & 12 & 7 & 4 & 4 & 10 & 4 & 2 \\
\hline Bangladesh & 142 & 18 & 8 & 238 & 56 & 11 & 378 & 306 & 10 \\
\hline & & & & & & & & & \\
\hline Total & 399 & 117 & 31 & 370 & 115 & 28 & 965 & 445 & 16 \\
\hline
\end{tabular}


Table 3 : Summary statistics

\begin{tabular}{|c|c|c|c|c|c|c|c|c|c|c|}
\hline & $\begin{array}{l}\text { Value } \\
\text { added / } \\
\text { Labour } \\
(2)\end{array}$ & $\begin{array}{l}\text { Capital / } \\
\text { Labour } \\
\text { (3) }\end{array}$ & Labor & $\begin{array}{c}\text { Capacity } \\
\text { utilization } \\
\text { (CAPUT) } \\
\text { (5) }\end{array}$ & $\begin{array}{l}R D \\
\text { activi- } \\
\text { ties } \\
\quad(6)\end{array}$ & $\begin{array}{l}\text { EDUCG } \\
M\end{array}$ & $\begin{array}{l}\text { LICENCE } \\
\text { from } \\
\text { abroad } \\
\quad(8)\end{array}$ & $\begin{array}{l}\text { Imported } \\
\text { machinery } \\
(I M P M A C) \\
(9)\end{array}$ & CREDIT & $\begin{array}{l}\text { REGUL- } \\
\text { TIME }\end{array}$ \\
\hline \multicolumn{11}{|l|}{$\begin{array}{l}\text { FOOD \& } \\
\text { BEVERAGES }\end{array}$} \\
\hline Brazil & $9.3(1.2)$ & $8.6(1.8)$ & $4.8(1.4)$ & $0.74(0.21)$ & 39.6 & 59.5 & 2.7 & 6.3 & 75.7 & $8.6(11.7)$ \\
\hline Ecuador & $8.5(1.4)$ & $8.7(1.5)$ & $3.8(1.4)$ & $0.67(0.23)$ & 51.0 & 83.7 & 22.5 & 71.4 & 69.4 & $15.9(13.4)$ \\
\hline South Africa & $9.9(1.1)$ & $8.6(1.0)$ & $5.0(1.4)$ & $0.77(0.15)$ & 61.1 & 83.3 & 16.7 & 38.9 & 83.3 & $8.3(6.4)$ \\
\hline Tanzania & $8.2(1.0)$ & 9.0 (1.9) & $4.0(1.5)$ & $0.57(0.22)$ & 14.8 & 70.5 & 21.3 & 29.5 & 36.1 & 17.1 (17.9) \\
\hline Bangladesh & 7.8 (1.3) & 7.5 (1.7) & $4.0(1.4)$ & $0.79(0.17)$ & 28.2 & 73.2 & 0.7 & 16.2 & 51.4 & 3.0 \\
\hline \multicolumn{11}{|l|}{ TEXTILES } \\
\hline Brazil & $9.6(1.3)$ & $8.8(1.3)$ & $4.3(1.3)$ & 0.77 (0.19) & 43.0 & 60.1 & 5.4 & 30.1 & 78.5 & $10.1(10.2)$ \\
\hline Ecuador & $9.0(0.9)$ & $8.7(1.2)$ & $4.0(1.2)$ & $0.63(0.27)$ & 40.0 & 80.0 & 10.0 & 85.0 & 75.0 & $11.6(8.0)$ \\
\hline South Africa & $9.4(0.6)$ & $8.2(1.4)$ & $6.0(1.5)$ & $0.84(0.14)$ & 58.3 & 100.0 & 16.7 & 50.0 & 58.3 & 8.1 \\
\hline Tanzania & $7.8(0.8)$ & $9.9(1.2)$ & 4.9 (1.3) & $0.63(0.24)$ & 14.3 & 57.1 & 28.6 & 14.3 & 57.1 & $26.5(27.1)$ \\
\hline Bangladesh & $7.7(0.9)$ & $7.9(1.2)$ & $5.3(1.1)$ & $0.78(0.16)$ & 35.3 & 63.8 & 2.9 & 39.1 & 75.6 & 4.5 (5.4) \\
\hline \multicolumn{11}{|l|}{$\begin{array}{l}\text { GARMENTS } \\
\text { \& LEATHER }\end{array}$} \\
\hline Brazil & $8.3(1.1)$ & $7.0(1.4)$ & $3.9(1.0)$ & $0.75(0.16)$ & 46.5 & 40.6 & 5.3 & 15.5 & 73.2 & $6.7 \quad(6.8)$ \\
\hline Ecuador & $8.7(1.7)$ & 7.7 (1.4) & $3.7(0.8)$ & $0.64(0.25)$ & 56.5 & 78.3 & 8.7 & 73.9 & 78.3 & $15.8(21.6)$ \\
\hline South Africa & $8.9(1.0)$ & 7.8 (1.6) & $5.5(1.4)$ & $0.83(0.15)$ & 44.0 & 84.0 & 16.0 & 36.0 & 84.0 & $14.2(16.6)$ \\
\hline Tanzania & $6.8(1.5)$ & $7.8(2.2)$ & $3.3(1.6)$ & $0.56(0.24)$ & 20.0 & 40.0 & 20.0 & 30.0 & 30.0 & $10.7(15.5)$ \\
\hline Bangladesh & $7.6(0.8)$ & $6.6(1.5)$ & $5.5(1.0)$ & $0.77(0.18)$ & 45.8 & 89.2 & 2.7 & 52.4 & 64.0 & 4.2 (3.9) \\
\hline
\end{tabular}
Note: columns 6 to 9 present proportions of firms for which the variable takes the value one; column 2 to 5 and 11 present mean values with
standard deviations in parentheses. See section 4 for more details on the variables. 
Table 4: OLS estimation results with technological and institutional variables

\begin{tabular}{|c|c|c|c|c|c|c|}
\hline & food & food & textiles & textiles & garm\&leath & garm\&leath \\
\hline \multirow[t]{2}{*}{$\mathrm{lkl02}$} & $0.293^{* * *}$ & $0.294^{* * *}$ & $0.245^{* * *}$ & $0.238 * * *$ & $0.295^{* * *}$ & $0.290 * * *$ \\
\hline & $(0.037)$ & $(0.037)$ & $(0.045)$ & $(0.043)$ & $(0.026)$ & $(0.026)$ \\
\hline \multirow[t]{2}{*}{ ltl02 } & 0.005 & 0.000 & -0.008 & -0.017 & 0.016 & 0.013 \\
\hline & $(0.047)$ & $(0.046)$ & $(0.042)$ & $(0.040)$ & $(0.033)$ & $(0.033)$ \\
\hline \multirow[t]{2}{*}{ caput } & $0.877 * * *$ & $0.911^{* * *}$ & 0.401 & 0.483 & $0.442 * *$ & $0.455 * *$ \\
\hline & $(0.267)$ & $(0.272)$ & $(0.371)$ & $(0.338)$ & $(0.185)$ & $(0.186)$ \\
\hline \multirow[t]{2}{*}{ ecua } & $-1.392 * * *$ & $-1.387 * * *$ & -0.234 & -0.051 & 1.372 & 1.390 \\
\hline & $(0.375)$ & $(0.385)$ & $(0.237)$ & $(0.214)$ & $(1.160)$ & (1.179) \\
\hline \multirow[t]{2}{*}{ safr } & 0.224 & 0.230 & -0.229 & $-0.381^{*}$ & 0.094 & 0.066 \\
\hline & $(0.198)$ & $(0.206)$ & $(0.186)$ & $(0.213)$ & $(0.216)$ & $(0.219)$ \\
\hline \multirow[t]{2}{*}{$\tan z$} & $-1.118^{* * *}$ & $-1.335^{* * *}$ & $-1.673 * * *$ & $-1.985^{* * *}$ & $-1.687 * * *$ & $-1.319 * * *$ \\
\hline & $(0.181)$ & $(0.328)$ & $(0.439)$ & $(0.700)$ & $(0.247)$ & $(0.287)$ \\
\hline \multirow[t]{2}{*}{ bang } & $-1.279 * * *$ & $-1.434 * * *$ & $-1.681^{* * *}$ & $-2.112 * * *$ & $-0.790 * * *$ & -0.299 \\
\hline & $(0.158)$ & $(0.313)$ & $(0.145)$ & $(0.483)$ & $(0.100)$ & $(0.187)$ \\
\hline \multirow[t]{2}{*}{ rd } & 0.109 & 0.208 & $0.393 * * *$ & $0.451 * *$ & $0.115^{*}$ & $0.221^{* *}$ \\
\hline & $(0.124)$ & $(0.173)$ & $(0.089)$ & $(0.176)$ & $(0.061)$ & $(0.087)$ \\
\hline \multirow[t]{2}{*}{ ldcrd } & & -0.242 & & -0.079 & & $-0.288^{* * *}$ \\
\hline & & $(0.236)$ & & $(0.202)$ & & $(0.113)$ \\
\hline \multirow[t]{2}{*}{ Educgm } & $0.497 * * *$ & $0.494^{* * *}$ & -0.022 & 0.121 & $0.246^{* * *}$ & $0.289 * * *$ \\
\hline & $(0.124)$ & $(0.181)$ & $(0.098)$ & $(0.233)$ & $(0.080)$ & $(0.097)$ \\
\hline \multirow[t]{2}{*}{ ldceducgm } & & -0.027 & & -0.152 & & -0.245 \\
\hline & & $(0.243)$ & & $(0.253)$ & & $(0.166)$ \\
\hline \multirow[t]{2}{*}{ licence } & 0.302 & 0.277 & 0.101 & 0.076 & $0.333 * * *$ & $0.321 * *$ \\
\hline & $(0.246)$ & $(0.248)$ & $(0.274)$ & $(0.269)$ & $(0.126)$ & $(0.127)$ \\
\hline \multirow[t]{2}{*}{ necuimpmac } & 0.202 & 0.174 & $0.327 * * *$ & $0.304 * * *$ & 0.012 & 0.015 \\
\hline & $(0.155)$ & $(0.155)$ & $(0.110)$ & $(0.114)$ & $(0.067)$ & $(0.067)$ \\
\hline \multirow[t]{2}{*}{ ecuimpmac } & 0.684 & 0.682 & -0.162 & -0.416 & -1.632 & -1.705 \\
\hline & $(0.429)$ & $(0.432)$ & $(0.263)$ & $(0.291)$ & $(1.167)$ & (1.185) \\
\hline \multirow[t]{2}{*}{ foreign } & $0.624^{* * *}$ & $0.602 * *$ & 0.104 & 0.129 & 0.349 & 0.387 \\
\hline & $(0.231)$ & $(0.232)$ & $(0.215)$ & $(0.218)$ & $(0.240)$ & $(0.251)$ \\
\hline \multirow[t]{2}{*}{ regultime } & -0.007 & $-0.010^{*}$ & $-0.010^{*}$ & -0.010 & $-0.010^{* *}$ & $-0.009 *$ \\
\hline & $(0.005)$ & $(0.006)$ & $(0.006)$ & $(0.009)$ & $(0.004)$ & $(0.005)$ \\
\hline \multirow[t]{2}{*}{ ldcregultime } & & 0.009 & & -0.003 & & -0.011 \\
\hline & & $(0.008)$ & & $(0.011)$ & & $(0.010)$ \\
\hline \multirow[t]{2}{*}{ credit } & $0.229 *$ & 0.052 & 0.017 & -0.487 & $0.198 * * *$ & $0.247 * *$ \\
\hline & $(0.133)$ & $(0.215)$ & $(0.142)$ & $(0.328)$ & $(0.067)$ & $(0.101)$ \\
\hline \multirow[t]{2}{*}{ ldccredit } & & 0.316 & & $0.744^{* *}$ & & -0.163 \\
\hline & & $(0.248)$ & & $(0.346)$ & & $(0.131)$ \\
\hline \multirow[t]{2}{*}{ Constant } & $5.601 * * *$ & $5.716^{* * *}$ & $6.947 * * *$ & $7.267 * * *$ & $5.627 * * *$ & $5.558 * * *$ \\
\hline & $(0.407)$ & $(0.434)$ & $(0.492)$ & $(0.635)$ & $(0.274)$ & $(0.277)$ \\
\hline Observations & 389 & 389 & 365 & 365 & 956 & 956 \\
\hline R-squared & 0.49 & 0.50 & 0.54 & 0.55 & 0.34 & 0.35 \\
\hline
\end{tabular}

Robust standard errors in parentheses

* significant at 10\%; ** significant at 5\%; *** significant at $1 \%$ 


\section{APPENDIX}

Table A1: Results of the weighted regression

\begin{tabular}{|c|c|c|c|}
\hline & food & textiles & garm\&leath \\
\hline \multirow[t]{2}{*}{$\mathrm{lkl02}$} & $0.290 * * *$ & $0.243^{* * *}$ & $0.301^{* * *}$ \\
\hline & $(0.040)$ & $(0.041)$ & $(0.029)$ \\
\hline \multirow[t]{2}{*}{ lt102 } & -0.005 & -0.002 & 0.032 \\
\hline & $(0.053)$ & $(0.039)$ & $(0.035)$ \\
\hline \multirow[t]{2}{*}{ bang } & $-1.320 * * *$ & $-2.199 * * *$ & -0.234 \\
\hline & $(0.365)$ & $(0.601)$ & $(0.201)$ \\
\hline \multirow[t]{2}{*}{ ecua } & $-1.449 * * *$ & 0.007 & 1.343 \\
\hline & $(0.398)$ & $(0.228)$ & (1.184) \\
\hline \multirow[t]{2}{*}{ safr } & 0.289 & $-0.420^{*}$ & 0.018 \\
\hline & $(0.211)$ & $(0.252)$ & $(0.227)$ \\
\hline \multirow[t]{2}{*}{$\operatorname{tanz}$} & $-1.224 * * *$ & $-2.016 * * *$ & $-1.217 * * *$ \\
\hline & $(0.371)$ & $(0.753)$ & $(0.317)$ \\
\hline \multirow[t]{2}{*}{ caput } & $0.757^{* *}$ & $0.652 * *$ & $0.445^{* *}$ \\
\hline & $(0.318)$ & $(0.303)$ & $(0.192)$ \\
\hline \multirow[t]{2}{*}{$\mathrm{rd}$} & $0.330 *$ & $0.497 * *$ & $0.217^{* *}$ \\
\hline & $(0.198)$ & $(0.215)$ & $(0.091)$ \\
\hline \multirow[t]{2}{*}{ ldcrd } & -0.363 & -0.127 & $-0.301^{* *}$ \\
\hline & $(0.246)$ & $(0.238)$ & $(0.117)$ \\
\hline \multirow[t]{2}{*}{ Educgm } & $0.524^{* *}$ & 0.039 & $0.296 * * *$ \\
\hline & $(0.218)$ & $(0.245)$ & $(0.092)$ \\
\hline \multirow[t]{2}{*}{ ldceducgm } & -0.174 & -0.062 & $-0.303^{*}$ \\
\hline & $(0.271)$ & $(0.259)$ & $(0.167)$ \\
\hline \multirow[t]{2}{*}{ licence } & 0.226 & 0.026 & $0.302 * *$ \\
\hline & $(0.255)$ & $(0.370)$ & $(0.147)$ \\
\hline \multirow[t]{2}{*}{ necuimpmac } & -0.046 & $0.349 * * *$ & 0.031 \\
\hline & $(0.168)$ & $(0.120)$ & $(0.071)$ \\
\hline \multirow[t]{2}{*}{ ecuimpmac } & 0.696 & -0.422 & -1.697 \\
\hline & $(0.438)$ & $(0.320)$ & (1.198) \\
\hline \multirow[t]{2}{*}{ foreign } & $0.589 * *$ & 0.200 & 0.081 \\
\hline & $(0.268)$ & $(0.276)$ & $(0.303)$ \\
\hline \multirow[t]{2}{*}{ regultime } & -0.010 & -0.010 & -0.003 \\
\hline & $(0.008)$ & $(0.010)$ & $(0.005)$ \\
\hline \multirow[t]{2}{*}{ ldcregultime } & 0.009 & -0.006 & -0.013 \\
\hline & $(0.009)$ & $(0.012)$ & $(0.011)$ \\
\hline \multirow[t]{2}{*}{ credit } & -0.028 & -0.545 & $0.261^{* * *}$ \\
\hline & $(0.253)$ & $(0.453)$ & $(0.100)$ \\
\hline \multirow[t]{2}{*}{ ldccredit } & 0.404 & $0.806^{*}$ & -0.181 \\
\hline & $(0.261)$ & $(0.465)$ & $(0.132)$ \\
\hline \multirow[t]{2}{*}{ Constant } & $5.893 * * *$ & $7.081^{* * *}$ & $5.369 * * *$ \\
\hline & $(0.497)$ & $(0.736)$ & $(0.291)$ \\
\hline Observations & 389 & 365 & 956 \\
\hline R-squared & 0.49 & 0.50 & 0.33 \\
\hline
\end{tabular}

Robust standard errors in parentheses; * significant at 10\%; ** significant at 5\%; *** significant at $1 \%$ 
Table A2: Results of the LAD estimation

\begin{tabular}{|c|c|c|c|}
\hline & food & textiles & garm\&leath \\
\hline \multirow[t]{2}{*}{ lkl02 } & $0.290 * * *$ & $0.238 * * *$ & $0.286^{* * *}$ \\
\hline & $(0.050)$ & $(0.045)$ & $(0.024)$ \\
\hline \multirow{2}{*}{ lt102 } & 0.007 & -0.008 & -0.009 \\
\hline & $(0.052)$ & $(0.051)$ & $(0.040)$ \\
\hline \multirow[t]{2}{*}{ bang } & $-1.400 * * *$ & $-1.891 * * *$ & -0.231 \\
\hline & $(0.475)$ & $(0.381)$ & $(0.193)$ \\
\hline \multirow[t]{2}{*}{ ecua } & -0.833 & -0.208 & 0.714 \\
\hline & $(0.549)$ & $(0.367)$ & $(0.983)$ \\
\hline \multirow[t]{2}{*}{ safr } & $0.425^{* *}$ & -0.142 & 0.202 \\
\hline & $(0.201)$ & $(0.255)$ & $(0.227)$ \\
\hline \multirow[t]{2}{*}{$\operatorname{tanz}$} & $-1.578 * * *$ & $-1.525 *$ & $-1.593 * * *$ \\
\hline & $(0.509)$ & $(0.845)$ & $(0.522)$ \\
\hline \multirow[t]{2}{*}{ caput } & $0.892^{* *}$ & 0.417 & 0.292 \\
\hline & $(0.350)$ & $(0.305)$ & $(0.242)$ \\
\hline \multirow[t]{2}{*}{$\mathrm{rd}$} & 0.157 & $0.506^{* * *}$ & $0.387 * * *$ \\
\hline & $(0.208)$ & $(0.175)$ & $(0.102)$ \\
\hline \multirow[t]{2}{*}{ ldcrd } & -0.331 & -0.083 & $-0.448 * * *$ \\
\hline & $(0.323)$ & $(0.220)$ & $(0.140)$ \\
\hline \multirow[t]{2}{*}{ Educgm } & 0.348 & -0.046 & $0.206^{* *}$ \\
\hline & $\begin{array}{l}(0.221) \\
\end{array}$ & $(0.218)$ & $\begin{array}{l}(0.100) \\
\end{array}$ \\
\hline \multirow[t]{2}{*}{ ldceducgm } & -0.145 & 0.079 & -0.248 \\
\hline & $(0.348)$ & $(0.245)$ & $(0.176)$ \\
\hline \multirow[t]{2}{*}{ licence } & 0.301 & 0.065 & 0.216 \\
\hline & $(0.284)$ & $(0.454)$ & $(0.177)$ \\
\hline \multirow[t]{2}{*}{ necuimpmac } & $0.349^{* *}$ & $0.286 * *$ & 0.026 \\
\hline & $(0.174)$ & $(0.115)$ & $(0.073)$ \\
\hline \multirow[t]{2}{*}{ ecuimpmac } & 0.610 & -0.050 & -0.910 \\
\hline & $(0.612)$ & $(0.452)$ & (1.042) \\
\hline \multirow[t]{2}{*}{ foreign } & 0.451 & 0.172 & 0.490 \\
\hline & $(0.304)$ & $(0.342)$ & $(0.494)$ \\
\hline \multirow[t]{2}{*}{ regultime } & -0.010 & -0.006 & $-0.012 * *$ \\
\hline & $(0.008)$ & $(0.010)$ & $(0.006)$ \\
\hline \multirow[t]{2}{*}{ ldcregultime } & 0.020 & -0.008 & 0.004 \\
\hline & $(0.013)$ & $(0.014)$ & $(0.014)$ \\
\hline \multirow[t]{2}{*}{ credit } & -0.209 & -0.225 & $0.301^{* * *}$ \\
\hline & $(0.345)$ & $(0.242)$ & $(0.101)$ \\
\hline \multirow[t]{2}{*}{ ldccredit } & 0.341 & 0.458 & $-0.255^{*}$ \\
\hline & $(0.379)$ & $(0.278)$ & $\begin{array}{l}(0.137) \\
\end{array}$ \\
\hline \multirow[t]{2}{*}{ Constant } & $6.006 * * *$ & $6.994^{* * *}$ & $5.723 * * *$ \\
\hline & $(0.599)$ & $(0.538)$ & $(0.327)$ \\
\hline Observations & 389 & 365 & 956 \\
\hline
\end{tabular}

Standard errors in parentheses ; * significant at $10 \%$; ** significant at $5 \%$; ** significant at $1 \%$ 